\title{
"Patent UnReasonableness is Dead. AND WE HAVE KILLED IT.” A CRITIQUE OF THE SUPREME COURT OF CANADA's DECISION IN DUNSMUIR
}

\author{
RON GOLTZ*
}

Upon arriving back to work after a brief yet refreshing trip to Las Vegas, my colleague burst into my office lamenting, "The Supreme Court has completely changed administrative law! They have killed off patent unreasonableness as a standard of review!” I felt an ominous sinking feeling, a sense of shock, and heartache, akin to the pain and loss that I felt when Tony Soprano pinched the nostrils of his nephew Christopher and watched him drift off into the great unknown. I hurriedly printed off the 7 March 2008, Supreme Court of Canada decision in Dunsmuir v. New Brunswick, ${ }^{1}$ and read it with bated breath, expecting the worst, yet hoping to find renewal and perhaps even a sort of rebirth into a fabulous new world of administrative law.

What I discovered was that, in the words of Michael Stipe, it may be the end of the world as I know it, yet I still feel fine.

\section{THE FACTS}

Mr. Dunsmuir was employed by the Department of Justice for the Province of New Brunswick as a legal officer. This position was "at pleasure" though, pursuant to the provisions of the Civil Service Act, ${ }^{2}$ his employment was governed by the ordinary rules of contract. After multiple reprimands for unacceptable performance, Dunsmuir was dismissed without cause and given four months pay in lieu of notice. He filed a grievance under the Public Service Labour Relations Act, ${ }^{3}$ alleging a lack of reasons for his employer's dissatisfaction, a lack of an opportunity to respond, and insufficient notice. The grievance was denied and the matter proceeded to adjudication. The adjudicator found, in a preliminary determination, that he had jurisdiction to determine the reasons for the decision to terminate and jurisdiction to reinstate the applicant. In a subsequent decision pertaining to the appropriate notice award, the adjudicator found that due to the hybrid nature of Dunsmuir's employment, he was entitled to and did not receive procedural fairness in the decision to terminate. Accordingly, the adjudicator ordered him reinstated, found that his termination was void $a b$ initio, and provisionally found that if the reinstatement was quashed on judicial review, then the appropriate notice period would be eight months.

On judicial review, the Court of Queen's Bench found that the correctness standard applied to the preliminary decision. The Court quashed this decision on the basis that the adjudicator did not have jurisdiction to look into the reasons for the applicant's dismissal, as he only had the authority to determine whether the notice given was reasonable. On the substantive decision relating to reinstatement and the appropriate notice award, the Court

Legal Counsel for the Alberta Workers’ Compensation Board and Sessional Instructor, Faculty of Law, University of Alberta.

2008 SCC 9, [2008] 1 S.C.R. 190 [Dunsmuir].

S.N.B. 1984, c. C-5.1.

R.S.N.B. 1973, c. P-25. 
found that Dunsmuir had received procedural fairness, though concluded that the adjudicator's decision did not stand up to review on a reasonableness simpliciter standard. Thus, the Court quashed the reinstatement order, but upheld the provisional award of eight months notice.

On appeal, the Court of Appeal agreed that Dunsmuir's right to procedural fairness had not been breached. It also held that the proper standard of review with respect to the interpretation of the adjudicator's authority was reasonableness simpliciter, not correctness. Nevertheless, the decision to reinstate was unreasonable as the applicant, in the circumstances, could only grieve the length of the notice period.

\section{THE ISSUES}

The two issues before the Supreme Court were: (1) the proper approach to be taken in a judicial review of a decision of an administrative tribunal, that is, the determination of the applicable standard of review; and (2) the application of the right of procedural fairness to individuals who hold "at pleasure” offices in the civil service. ${ }^{4}$

The first paragraph of the decision noted the central problem with administrative law:

This appeal calls on the Court to consider, once again, the troubling question of the approach to be taken in judicial review of decisions of administrative tribunals. The recent history of judicial review in Canada has been marked by ebbs and flows of deference, confounding tests and new words for old problems, but no solutions that provide real guidance for litigants, counsel, administrative decision makers or judicial review judges. The time has arrived for a reassessment of the question. ${ }^{5}$

Like any good law school paper, the decision articulated its goals and focus early on:

Despite the clear, stable constitutional foundations of the system of judicial review, the operation of judicial review in Canada has been in a constant state of evolution over the years, as courts have attempted to devise approaches to judicial review that are both theoretically sound and effective in practice. Despite efforts to refine and clarify it, the present system has proven to be difficult to implement. The time has arrived to reexamine the Canadian approach to judicial review of administrative decisions and develop a principled framework that is more coherent and workable.

[I]t has become apparent that the present system must be simplified. 
In our view, it is necessary to reconsider both the number and definitions of the various standards of review, and the analytical process employed to determine which standard applies in a given situation. We conclude that there ought to be two standards of review — correctness and reasonableness. ${ }^{6}$

Thus, the stated goals of the Court were:

- To develop a coherent, workable, and principled framework to judicial review;

- $\quad$ To simplify judicial review; and

- To reduce the number and definitions of the standards of review to two.

While laudable in its attempt, the decision failed to meet the Court's articulated aspirations. In fact, Dunsmuir, when read as a whole with the separate yet concurring decisions, serves to infuse increased uncertainty into an already enigmatic area of the law. Instead of simplifying the tests and focusing the arguments, the Court opened up new avenues for debate, discussion, and litigation.

\section{THE DECISION}

Writing on behalf of the majority, Bastarache and LeBel JJ. began their analysis with a review of the fundamental principles of judicial review, noting the inherent tension between the rule of law and democracy. The initial focus of their critique of the previous pragmatic and functional approach, and its accompanying three-headed spectrum of standards, was on the ability to distinguish between patent unreasonableness and reasonableness simpliciter. Moreover, the majority lamented that the application of the patent unreasonableness standard requires parties to accept unreasonable decisions. ${ }^{7}$ In their opinion, it is inconsistent with the rule of law to retain an irrational decision. ${ }^{8}$ As both discretionary standards acknowledge that there may be multiple valid interpretations of statutory provisions or answers to legal questions, and owing to the fact that courts ought not interfere where the tribunal's decision is rationally supported, a "simpler" test was created:

\footnotetext{
We therefore conclude that the two variants of reasonableness review should be collapsed into a single form of "reasonableness" review. The result is a system of judicial review comprising two standards — correctness and reasonableness. But the revised system cannot be expected to be simpler and more workable unless the concepts it employs are clearly defined. ${ }^{10}$
}

Ibid. at paras. 32-34, 43.

Ibid. at para. 39.

Ibid. at para. 42.

Ibid. at para. 43.

Ibid. at para. 45 . 
Thus, the Court in Dunsmuir expanded on LeBel J.'s comments in Voice Construction Ltd. v. Construction \& General Workers' Union, Local 92, ${ }^{11}$ declaring that the standard of "patent unreasonableness" is now dead. ${ }^{12}$ The new articulation of "reasonableness" is as follows:

\begin{abstract}
Reasonableness is a deferential standard animated by the principle that underlies the development of the two previous standards of reasonableness: certain questions that come before administrative tribunals do not lend themselves to one specific, particular result. Instead, they may give rise to a number of possible, reasonable conclusions. Tribunals have a margin of appreciation within the range of acceptable and rational solutions. A court conducting a review for reasonableness inquires into the qualities that make a decision reasonable, referring both to the process of articulating the reasons and to outcomes. In judicial review, reasonableness is concerned mostly with the existence of justification, transparency and intelligibility within the decisionmaking process. But it is also concerned with whether the decision falls within a range of possible, acceptable outcomes which are defensible in respect of the facts and law. ${ }^{13}$
\end{abstract}

The Court was careful to point out that collapsing both deferential standards into one should not pave the way for more intrusion by the courts, as deference is "both an attitude of the court and a requirement of the law of judicial review." ${ }^{\text {"14 }}$

Justice Binnie's separate concurring reasons shifted the debate "from choosing between two standards of reasonableness that each represent a different level of deference to a debate within a single standard of reasonableness to determine the appropriate level of deference,"15 creating the potentially infamous "big tent" standard of reasonableness. ${ }^{16}$ Thus, the level of reasonableness to be afforded to a particular decision will depend on the context and must be calibrated to fit the circumstances. In other words, reasonableness is not a fixed standard, but rather a spectrum itself encompassing varying amounts of judicial deference. The concurring reasons of Deschamps, Charron, and Rothstein JJ. appeared to support this conclusion, comparing the contextual analysis to a rainbow, rather than a black and white situation. ${ }^{17}$

The practice of determining which of the two standards to apply was also changed. Adopting a rationale previously articulated by certain justices of the Alberta courts, ${ }^{18}$ the Supreme Court accepted the doctrine of stare decisis in certain contexts, potentially removing the requirement for a review of the relevant factors. In this regard, Bastarache and LeBel JJ. wrote:

2004 SCC 23, [2004] 1 S.C.R. 609 at paras. 41-42 [Voice Construction].

Supra note 1 at paras. 45, 134.

Ibid. at para. 47 [emphasis added].

Ibid. at paras. 48, 141.

Ibid. at para. 139 [emphasis in original].

Ibid. at para. 144.

Ibid. at para. 167.

See the comments of Slatter J. (as he then was) in White v. Alberta (Workers' Compensation Board Appeals Commission), 2006 ABQB 359, 400 A.R. 183 at paras. 24-31 [White]. See also the comments of Berger J.A. in Nabors Canada LP v. Alberta (Workers’ Compensation Appeals Commission), 2006 ABCA 371, 397 A.R. 57 at paras. 10-16 [Nabors]. 
An exhaustive review is not required in every case to determine the proper standard of review. Here again, existing jurisprudence may be helpful in identifying some of the questions that generally fall to be determined according to the correctness standard. This simply means that the analysis required is already deemed to have been performed and need not be repeated. ${ }^{19}$

Examples of presumptive principles and issues conclusively determined and not requiring an exhaustive analysis include the following:

- The existence of a privative clause gives rise to a strong indication of review pursuant to the reasonableness standard; ${ }^{20}$

- "Where the question is one of fact, discretion or policy," or "where the legal and factual issues are intertwined with and cannot be readily separated," "deference will usually apply automatically"; ${ }^{21}$

- Where the "tribunal is interpreting its own statute or statutes closely connected to its function, with which it will have particular familiarity,” deference will usually apply; $;^{22}$

- Constitutional questions are necessarily subject to correctness review; ${ }^{23}$

- $\quad$ True questions of jurisdiction or vires attract the correctness standard; ${ }^{24}$ and

- The correctness standard must apply to questions of law that are of central importance to the legal system as a whole which are outside of the specialized area of expertise of the administrative decision-maker. ${ }^{25}$

The Supreme Court also noted that where the applicable standard has not previously been conclusively determined, an examination of the contextual factors will be required, that is, those previously employed in the pragmatic and functional analysis, though only one of the factors may be determinative. ${ }^{26}$ While correctness was maintained for jurisdictional questions and some questions of law (permitting the Court to substitute its own analysis), the "going-in presumption should be that the standard of review of any administrative outcome on grounds of substance is not correctness but reasonableness."27

Supra note 1 at para. 57 [footnotes omitted].

Ibid. at para. 52.

Ibid. at para. 53 [footnotes omitted].

Ibid. at para. 54 .

Ibid. at para. 58.

Ibid. at para. 59.

Ibid. at para. 60. However, at paras. 124, 128, Binnie J. expands on the application of correctness to issues pertaining to the common law and the interpretation of statutes other than the administrative body's enabling statute. The concurring reasons of Deschamps, Charron, and Rothstein JJ. at para. 162, also would seem to encourage a broad application of the correctness standard to questions of law.

Ibid. at paras. 64, 160. Previous Alberta jurisprudence has also commented that a perfunctory analysis may suffice in certain circumstances. See the comments of Conrad J.A. in Nabors, supra note 18 at para. 49; Ritter J.A. in Foster v. Alberta (Transportation and Safety Board), 2006 ABCA 282, 397 A.R. 82 at para. 8 [Foster].

Dunsmuir, ibid. at para. 146. 
What we are left with is the renamed multi-stage "standard of review analysis". ${ }^{28}$

[T] he process of judicial review involves two steps. First, courts ascertain whether the jurisprudence has already determined in a satisfactory manner the degree of deference to be accorded with regard to a particular category of question. Second, where the first inquiry proves unfruitful, courts must proceed to an analysis of the factors making it possible to identify the proper standard of review. ${ }^{29}$

On the issue of the application of procedural fairness to individuals who hold "at pleasure" offices in the civil service, the Court affirmed that the nature of the employment relationship between the employee and public employer is key. Moreover, the Court held that " $[w]$ here a public employee is employed under a contract of employment, regardless of his or her status as a public office holder, the applicable law governing his or her dismissal is the law of contract, not general principles arising out of public law.”30

Thus, the required amount of procedural fairness is dictated by the contract governing the employment relationship and not common law administrative law principles. Accordingly, those rights and obligations specified in the contract, for example, a right to a hearing, must be followed. Although there remains a general duty of fairness on administrative decisionmakers, disputes involving a dismissal from public employment should be viewed through the "lens of contract law rather than public law." ${ }^{31}$ In short, public law procedural fairness requirements are not to be imposed on public bodies in their exercise of contractual rights as employers. ${ }^{32}$ While a dismissal from a true "public office" (such as judges or ministers of the Crown - those with a "strong 'statutory flavour'”) $)^{33}$ will still attract a duty of procedural fairness, one must start with the presumption that employment relationships are contractual. ${ }^{34}$

\section{The ANALYsis}

Although the Court's clarification of the law respecting the application of procedural fairness to public employment situations is not insignificant, the focus of this comment will be on the practical impact of the decision in determining the applicable standard of review.

\section{A. ARE THINGS NOW REALLY "SIMPLER"?}

What does the decision mean for practising administrative law lawyers? Is the new "standard of review" analysis more coherent and workable? Prior to Dunsmuir, the pragmatic

Ibid. at paras. 63, 121.

Ibid. at para. 62.

Ibid. at para. 81.

Ibid. at para. 82.

Ibid. at paras. 103-104.

Ibid. at paras. 89, 94, 115 [footnotes omitted].

Ibid. at para. 113. 
and functional analysis was to be applied in its entirety, ${ }^{35}$ to each issue raised, ${ }^{36}$ to determine the legislative intent in respect of the amount of deference to be owed in the circumstances. ${ }^{37}$ The analysis of the factors led a court to select and apply one of three established standards of review. ${ }^{38}$

Under the new "simpler” Dunsmuir approach, a standard of review analysis may or may not be required if the issue has been previously determined by the courts. If the doctrine of stare decisis does not apply, one is to apply the previous pragmatic and functional factors, though no one factor is determinative. If one of the factors is not determinative, one must apply the factors in their entirety, to determine if one of two standards will apply. While one of these standards is well established, the other may or may not encompass a "big tent" or "rainbow" - a potential myriad of standards of review.

The first and most obvious critique of the new approach is that it does not provide the stated clarity strived for by the Court. Are there two or an infinite number of standards? How closely must the facts and law be to previous judicial precedent for the doctrine of stare decisis to apply? Has expertise remained the most important factor in the analysis, or is the nature of the question fundamental, especially in the face of a statutory right of appeal? ${ }^{39}$ The actual application of these standards (whether they be two or infinite) is likely to be the subject of significant legal debate throughout Canada, absent further clarification by the Supreme Court.

Moreover, this new approach to administrative law is unlikely to simplify matters for practising lawyers. Given the potential for a court to disagree with counsel's submissions on matters such as whether the issue has been previously decided, the characterization of the relevant issues as ones of fact, law, or mixed law and fact, and so on, prudent practitioners will avoid the risk and address all issues with a full standard of review analysis, at least in the alternative. It also remains likely that opposing counsel will take different views of the facts and law, necessitating each to advance full but contrary analyses. Thus, one has to ask, how is this any simpler than before? What the new approach does is allow the court to circumvent its analysis in its decisions if it so chooses, but again, only at its own peril of being overturned on appeal for incorrectly adopting previous binding jurisprudence or improperly characterizing the matters before it.

Pushpanathan v. Canada (Minister of Citizenship and Immigration), [1998] 1 S.C.R. 982 at para. 27 [Pushpanathan]; Voice Construction, supra note 11 at para. 18; Dr. Q v. College of Physicians and Surgeons of British Columbia, 2003 SCC 19, [2003] 1 S.C.R. 226 at paras. 25-26 [Dr. Q]. In Alberta, a perfunctory analysis was seen to be permissible in instances where the same issue was previously dealt with and determined. See Foster, supra note 26 at para. 8; Nabors, supra note 18 at para. 49.

Pushpanathan, ibid.; Voice Construction, ibid. at para. 19; Dr. Q, ibid. at para. 22.

Pushpanathan, ibid.

Ibid.; Dr. Q, supra note 35 at para. 22.

See e.g. the interplay between the exclusive jurisdiction and no certiorari clauses in ss. 13.1(1) and 13.1(9) of the Workers' Compensation Act, R.S.A. 2000, c. W-15 [WCA], as am. by Workers' Compensation Amendment Act, 2002, S.A. 2002, c. 27, and the statutory right of appeal from decisions of the Appeals Commission to the Alberta Court of Queen's Bench on questions of law or jurisdiction in s. 13.4 of the WCA. Thus, in cases where the nature of the question is one of law or jurisdiction, the statutory right of appeal takes precedence over the combinations clauses indicating less judicial deference. Conversely, where the nature of the question is one of fact or mixed fact and law, no statutory right of appeal exists and the privative clauses have full effect. 
Another practical consideration resulting from the concurring reasons of Binnie J. in Dunsmuir, is whether the standard of review analysis should be utilized to ascertain the degree of deference owed by a court to a decision where the reasonableness standard applies. In other words, should a standard of review analysis be conducted, not merely to choose the correct standard, but rather to determine the correct level of deference owed within the big tent of reasonableness? For example, where it is clear from previous precedent or from one of the contextual factors that reasonableness will apply rather than correctness, does Dunsmuir permit or in fact require a full analysis of all the contextual factors to determine the proper manifestation of reasonableness and level of deference to be afforded the decision? If this is in fact the case, the law has clearly taken a step backwards from workability, clarity, and focus. Yet, if reasonableness truly is a big tent or spectrum of standards as the decision conveys, there likely is no more practical way to determine the appropriate level of deference.

What is telling is that even with the more "principled ... more coherent and workable" 40 standard of review analysis and the reduction in named standards to two, the Supreme Court could still not agree on which standard applied. While the majority of the Court found that reasonableness should apply, ${ }^{41}$ Deschamps, Charron, and Rothstein JJ. found that correctness was applicable. $^{42}$

\section{B. SOME UNRESOLVED ISSUES ARISING OUT OF DUNSMUIR}

While the Supreme Court attempted in Dunsmuir to elucidate the quagmire that is administrative law and judicial review/appeal, in fact, more questions than answers arise out of the decision.

First, and most obviously, how many standards of review do we have exactly? While the answer was relatively clear before, the conjunction of the majority decision with the separate yet concurring decision of Binnie J. casts significant doubt on the issue. ${ }^{43}$ Under the pragmatic and functional approach, a court had three options - correctness, reasonableness simpliciter, and patent unreasonableness - aligning as distinct and specific points on a spectrum of standards. ${ }^{44}$ If we attempt to apply Dunsmuir as a whole, we sacrifice patent unreasonableness (at the very least in name) on the altar of change in exchange for the new "big tent" or "rainbow" of reasonableness. ${ }^{45}$

$40 \quad$ Supra note 1 at para. 32.

$41 \quad$ Ibid. at paras. $71,156$.

$42 \quad$ Ibid. at para. 168.

43 See Jacqueline R. Castel \& Omeela K. Latchman, The Practical Guide to Canadian Legal Research, 2d ed. (Scarborough: Carswell, 1996) at 6 [emphasis added]:

There are situations where the majority of the court agree to decide a case in a certain way and several judges write concurring opinions for the majority. These opinions may differ substantially in their reasoning. Such cases are troublesome to interpret because the exact law is not clearly defined. When dealing with these cases, your analysis must be sensitive to the reasoning employed in all of the concurring judgments. 
So what practically changes? It would appear that we have morphed from (1) one spectrum with three distinctive standards, to (2) one clearly established standard (that is, correctness) with a second separate standard (reasonableness) being a spectrum in and of itself encompassing an indefinite number of indefinable standards. It seems illogical for Binnie J. to argue that "the law of judicial review should be pruned of some of its unduly subtle, unproductive, or esoteric features" ${ }^{\text {"6 }}$ and then reintroduce the concept of "degrees of deference" within the new standard of reasonableness. For the sake of clarity and simplicity, we potentially have gone from three to an infinite number of standards of review, from the distinct to the formless, from the precise to the nebulous.

Second, what exactly is the new standard of reasonableness? Can it be equated generally to the old standard of reasonableness simpliciter? If so, how can that definition be reconciled with the Court's comments that the new approach should not signal more intrusion by the courts? If reasonableness is instead an amalgamation of the two previous standards into a new spectrum, does the range start with reasonableness simpliciter and end with patent unreasonableness? ${ }^{47}$ If that is the case, then we truly will have gained nothing as, in the ultimate triumph of form over substance, the elimination of the third standard of patent unreasonableness will have been in name only. Yet, if patent unreasonableness has been eliminated completely as a level of judicial deference, such an outcome must necessarily result in increased intrusion by the courts, something expressly rejected by Bastarache, LeBel, and Binnie $J J .^{48}$ It will be very intriguing to observe in the coming months how far lawyers will be able to extend the Court's interpretation of the new standard in each direction.

A third issue arises out of the application of the doctrine of stare decisis to the standard of review analysis, potentially fracturing the sepulchre and resurrecting patent unreasonableness. Under Dunsmuir, courts must examine and "ascertain whether the jurisprudence has already determined in a satisfactory manner the degree of deference to be accorded with regard to a particular category of question." ${ }^{49}$ However, what if all previous jurisprudence on the direct matter at issue clearly calls for the application of the dearly departed patent unreasonableness standard? For example, significant judicial pronouncement has asserted that patent unreasonableness applies to the decisions of Workers' Compensation Boards and their relevant appellate bodies, especially on the issue of eligibility for compensation, and other like issues of fact or mixed fact and law. ${ }^{50}$ Are all of these decisions to be ignored or discounted? Are they now bad law? Or do they in fact make up the elixir to

$46 \quad$ Ibid. at para. 133.

$47 \quad$ This contention is seemingly adopted by Binnie J. where he states, ibid. at para. 141: "[r]educing three standards of review to two standards of review does not alter the reality that at the high end 'patent' unreasonableness (in the sense of manifestly indefensible) was not a bad description of the hurdle an applicant had to get over to have an administrative decision quashed on a ground of substance.”

$48 \quad$ Ibid. at paras. 48, 141.

$49 \quad$ Ibid. at para. 62.

$50 \quad$ See e.g. Buckley v. Entz Estate, 2007 ABCA 7, 401 A.R. 231; Nabors, supra note 18; Alberta (Workers' Compensation Board) v. Alberta (Workers' Compensation Board Appeals Commission), 2005 ABCA 276, 371 A.R. 318; Alberta (Workers' Compensation Board) v. Alberta (Workers' Compensation Board Appeals Commission), 2005 ABCA 235, 371 A.R. 62; Michailides v. Alberta (Workers' Compensation Board), 1999 ABQB 941, 260 A.R. 323; Pasiechnykv. Saskatchewan (Workers' Compensation Board), [1997] 2 S.C.R. 890. 
help prolong the life of patent unreasonableness, permitting the standard to reside in the coldest, darkest corner of the reasonableness tent? If courts are to ignore or discount preDunsmuir jurisprudence calling for the application of the most deferential standard, is it still open for Parliament or the legislatures to enact legislation asserting the application of patent unreasonableness for certain issues? ${ }^{51}$ Such questions result from the underlying fundamental tension in administrative law between parliamentary sovereignty on the one hand, and the role of the courts in protecting the rule of law on the other. Only time and judicial pronouncement will tell whether the legislative authorities possess the power to raise the dead.

Fourth, are administrative lawyers and judges to apply the new standard of review analysis to instances of abuses of discretion? In the case of Baker v. Canada (Minister of Citizenship and Immigration), ${ }^{52}$ L'Heureux-Dubé J., on behalf of the majority, affirmed the application of the pragmatic and functional approach to instances of abuse of discretion, specifically on the nebulous ground of unreasonableness. ${ }^{53}$ In other words, reviewing courts were required to perform a pragmatic and functional analysis to determine the relevant standard of review and proper amount of judicial deference owed to an administrative tribunal's exercise of discretion:

\footnotetext{
This then led to the court recognizing for the first time explicitly that the "pragmatic and functional approach" was also of use in determining the intensity with which reviewing courts should be approaching decisions in the discretionary section of the spectrum between pure questions of law, at one end, and completely unfettered discretion to be exercised on the basis of the subjective judgment of the repository of power, at the other end. Standard of review discourse came to the world of abuse of discretion. ${ }^{54}$
}

Thus, a court could find one tribunal's unreasonable exercise of discretion to be tolerable if the standard of patent unreasonableness applied, while another's impermissible if a more intrusive standard was deemed appropriate. Though the application of the pragmatic and functional analysis to discretionary decisions in Baker was limited to the ground of unreasonableness, the inclusive language used in the decision implied that the same analysis should be utilized in all cases alleging an abuse of discretion on behalf of the administrative body. $^{55}$

This application of the law is both esoteric and arcane. Requiring lawyers to determine if a given abuse of discretion by an administrative board, tribunal, or agency would be permissible based on the relative expertise of that body or the existence of a strong privative clause belies the nature of abuses of discretion:

See e.g. Administrative Tribunals Act, S.B.C. 2004, c. 45, s. 58. For certain administrative tribunals, this Act sets the application of patent unreasonableness for findings of fact or law or exercises of discretion by the tribunal in respect of matters over which the tribunal has exclusive jurisdiction under a privative clause, and also provides examples of what constitutes patent unreasonableness.

[1999] 2 S.C.R. 817 [Baker].

Ibid. at paras. 52-56.

David J. Mullan, Administrative Law: Cases, Text, and Materials, 5th ed. (Toronto: Emond Montgomery, 2003) at 953.

$55 \quad$ Supra note 52 at para. 55. 
An abuse of discretion is an error which is jurisdictional in nature, even though the statutory delegate is properly constituted, has complied with all mandatory requirements, is dealing with the subject matter granted to it by the legislation, and undoubtedly has the right to exercise the discretionary power in question.

Thus, these errors make the delegate's action a nullity. Because it is nonsensical to say that anyone has jurisdiction to commit a nullity, these errors must deprive the delegate of its jurisdiction to exercise its discretion in that particular manner. ${ }^{56}$

It is illogical to assert that a tribunal should be permitted to be "unreasonable" in its bad faith, discrimination, or fettering of discretion. The application of the pragmatic and functional or the standard of review analysis to such grounds for judicial review is baseless. Administrative bodies should not be afforded varying degrees of deference in their exercises of discretion should such discretion be exercised in an unlawful manner. Like a switch, you either have an abuse of discretion or you do not - proving the existence of bad faith should automatically remove the jurisdiction of the tribunal irrespective of the statutory provisions or the tribunal's expertise.

The impact of Dunsmuir on this aspect of administrative law is not readily discernable. Further clarification on whether the new standard of review analysis will apply to some or all instances of abuse of discretion is necessary. While some discretionary abuses may lend themselves more readily to discussion within the realm of deference, ${ }^{57}$ it is submitted that the articulated goals of simplicity and coherence call for the traditional, more principled jurisdictional approach for all abuses of discretion.

\section{SubSEQUENT JUdicial TREATMENT OF DUNSMUIR}

The resolution of these issues will transpire through litigation and judicial pronouncement. As of writing this comment (June 2008), Dunsmuir has been noted in over 250 cases throughout Canada, with 65 decisions following its application and only one distinguishing it based on the salient facts. However, discrepancies in how to apply it have already developed, especially on the issue of reasonableness as either a fixed standard or spectrum. Brief mention of Dunsmuir is made by the Supreme Court of Canada in the more recent decision of Lake v. Canada (Minister of Justice), ${ }^{58}$ a case dealing with an exercise of

56 David Phillip Jones \& Anne S. de Villars, Principles of Administrative Law, 4th ed. (Scarborough: Thomson Carswell, 2004) at 169 [footnotes omitted].

57 Some instances of abuse of discretion such as irrelevant considerations and improper purpose clearly allow for legal discourse within the realm of deference. That is, in order to determine whether or not a consideration is relevant or not, one can, and likely should, examine some of the Pushpanathan (supra note 35) contextual factors; the nature of the question at issue, expertise of the tribunal, and the purpose of the tribunal as determined by its enabling legislation will help to ascertain whether one of their considerations was relevant or for a proper purpose. Nevertheless, it is submitted that such a discourse should not extend to permitting varying degrees of abuse of discretion depending on the tribunal at issue. In other words, the contextual factors should help to ascertain whether a consideration is relevant or not. However, once it is determined that the tribunal based its decision on an irrelevant consideration, the decision is ultra vires and should be set aside. See Mullan, supra note 54 at 953. 
discretion by the Minister of Justice in refusing to surrender an accused for extradition. While the Court found the appropriate standard of review to be reasonableness, it called for significant deference, stating " $[\mathrm{t}] \mathrm{he}$ assertion that interference with the Minister's decision will be limited to exceptional cases of 'real substance' reflects the breadth of the Minister's discretion; the decision should not be interfered with unless it is unreasonable.”59 The use of such language would seem to imply that varying amounts of deference do in fact exist under the banner of reasonableness. Correspondingly, in Canadian Union of Postal Workers v. Canada Post Corp. ${ }^{60}$ the British Columbia Supreme Court applied Dunsmuir and noted that "there may be different degrees of deference within the reasonableness standard." 61 They did not however provide further discussion on the point in adopting it as the relevant standard.

Conversely, the Alberta courts have generally applied reasonableness as a fixed standard, accepting the definition articulated by Bastarache and LeBel JJ. on behalf of the majority. ${ }^{62}$ In ATCO Gas and Pipelines Ltd. v. Alberta (Energy and Utilities Board), ${ }^{63}$ the Alberta Court of Appeal applied reasonableness as a set standard without mention of any tents, rainbows, or spectrums. In Calgary (City of) v. Alberta (Municipal Government Board), ${ }^{64}$ the Court of Appeal employed a full standard of review analysis and also accepted the majority's articulation of the reasonableness standard. Similar reasoning was also provided in Anderson v. Alberta Securities Commission, ${ }^{65}$ with the Court stating that "[d]eference is due to the Commission; its findings should be examined to see whether they are justified, transparent and intelligible, and whether the decision falls within a range of acceptable outcomes that are defensible in respect of the facts and the law." ${ }^{66}$ In short, it remains to be seen the extent to which litigants will attempt to push the boundaries of reasonableness, and the willingness of courts to adopt the big tent or rainbow paradigm.

Furthermore, and not surprisingly given their previous rulings, ${ }^{67}$ the Alberta courts have adopted the findings of Dunsmuir with respect to the application of the doctrine of stare decisis for previously decided questions. In ATCO Gas, ${ }^{68}$ the Alberta Court of Appeal selected reasonableness as the appropriate standard of review based on previous jurisprudence, and as noted, applied it as a fixed standard.

Interestingly, in the case of United Food and Commercial Workers' Union, Local $401 \mathrm{v}$. Real Canadian Superstore, ${ }^{69}$ the Alberta Court of Appeal adopted the old reasonableness simpliciter (as opposed to reasonableness) standard, mindful of Dunsmuir, and with the agreement of the parties. ${ }^{70}$

Ibid. at para. 34 [footnote omitted]. 2008 BCSC 338, [2008] B.C.J. No. 498 (QL).

Ibid. at para. 25.

Supra note 1 at para. 47.

2008 ABCA 200, [2008] A.J. No. 566 (QL) [ATCO Gas].

2008 ABCA 187, [2008] A.J. No. 541 (QL).

2008 ABCA 184, [2008] A.J. No. 516 (QL).

Ibid. at para. 29, citing Dunsmuir, supra note 1 at para. 47.

See White, supra note 18; Nabors, supra note 18.

Supra note 63.

2008 ABCA 210, [2008] A.J. No. 588 (QL).

Ibid. at para. 6 . 


\section{CONCLuSion}

Administrative law has always had esoteric elements to it. One of the joys that one can take from the practice of this branch of the law is the ability to argue and debate within its sullied milieu. That was the reason why many of us went to law school to begin with. In Dunsmuir, the Supreme Court of Canada attempted to clean up the clutter, confusion, and disarray that it, along with the practising bar, had created. However, the practical consequences do not match the aims. Instead of a more coherent, workable, and principled framework to judicial review, we have multiple contingent tests. Most strikingly, the Court appears to fail to even achieve the basic goal of reducing the number of standards of review.

What is plain is that administrative law could have been eminently more comprehensible had the Court issued one unified unambiguous decision. Without the separate reasons of Binnie, Deschamps, Charron, and Rothstein JJ., we would have had two standards of review, with relatively clear articulations of those standards. If there ever was a time which called for a cohesive stance from Canada's highest Court in the ambit of administrative law, this was it.

While it may be the end of the patent unreasonableness standard and the pragmatic and functional approach, I do, in fact, feel fine because life as an administrative lawyer will continue as it has, with practitioners fighting over subtle distinctions in the law, and judges issuing conflicting interpretations thereof. It certainly may be the case that I have missed the academic subtleties and nuances in this decision. However, given the stated goals of simplicity and coherency, I am sure I am not the only one who has missed the point. 